\author{
S.P. Danylchuk, O.V. Zamurujeva, V.E. Sakhnyuk, S.A. Fedosov
}

\title{
Photonic Properties of Devices Based on Multicomponent Crystalline Compounds with Content (Si, Ge, Sn)
}

\author{
Lesya Ukrainka Volyn National University, Lutsk, Ukraine, zamurueva.o@gmail.com
}

\begin{abstract}
The paper presents the results of optical and photoelectric measurements and their analysis for $\mathrm{Tl}_{1-x} \mathrm{In}_{1-x} \mathrm{D}^{\mathrm{IV}}{ }_{x} \mathrm{Se}_{2}\left(\mathrm{D}^{\mathrm{IV}}-\mathrm{Si}, \mathrm{Ge}, \mathrm{Sn}\right)$ crystalline compounds in the wavelength range $0.4 \div 1.4 \mu \mathrm{m}$ at a temperature $T=300 \mathrm{~K}$. The work aims to investigate the influence of mole fraction $\mathrm{D}^{\mathrm{IV}} \mathrm{Se}_{2}$ on the mechanisms of interband transitions and the basic photon parameters of crystals of $\mathrm{TlInSe}{ }_{2}-\mathrm{D}^{\mathrm{IV}} \mathrm{Se}_{2}$ solid solutions. It was found that the change in the physical properties of the mole fraction of the components $\mathrm{x}$ associated with the rearrangement of the band structure significantly expands the functionality of the $\mathrm{Tl}_{1-x} \mathrm{In}_{1-x}(\mathrm{Si}, \mathrm{Ge}, \mathrm{Sn})_{x} \mathrm{Se}_{2}(x \leq 0.25)$ crystalline compounds as promising materials for optoelectronic devices.
\end{abstract}

Keywords: crystal, mole fraction, direct and indirect transition, energy gap, absorption coefficient, photosensitivity.

Received 27 June 2021; Accepted 15 August 2021.

\section{Introduction}

Photonic devices are devices as light sources that convert electrical energy into optical radiation - the LED, devices that detect optical signals - photodetectors, devices that convert optical radiation into electrical energy - the photovoltaic device or solar cell.

The physics of semiconductor devices, of course, is determined by the physical properties of the semiconductor materials themselves. Modern technology development requires the use of materials with predefined properties.

For display applications, since the human eye is only sensitive to light of energy $h v \geq 1.8 \mathrm{eV}(\lambda \leq 0.7 \mu \mathrm{m})$, semiconductors for light- and photodevices in the visible range of interest must have energy bandgaps larger than this value. Direct-bandgap semiconductors are particularly important for electroluminescent devices, because the radiative recombination is a first-order transition process (no phonon involved) and the quantum efficiency is expected to be much higher than that for an indirect bandgap semiconductor, where a phonon is involved. At the same time, for photodevices, the main factor determining quantum efficiency is the absorption coefficient and the bandgap. Therefore, it is important to establish a mechanism for interband transitions to assess the feasibility of practical use of semiconductor materials as functional materials of photonic devices.

Complex semiconductor compounds with the general formula $\mathrm{A}^{\mathrm{I}} \mathrm{B}^{\mathrm{III}} \mathrm{C}_{2}{ }^{\mathrm{VI}}$ have technologically attractive properties for the creation of various optoelectronic devices. A number of crystals from this group are commercially available and have found application in the manufacture of nonlinear optics and solar cells. In particular, TlInSe $e_{2}$ crystals have a high sensitivity to near-infrared radiation, to hard radiation, show high radiation resistance [1], and are promising for the creation of radiation detectors and receivers, as well as functional devices controlled by electric fields operating in harsh conditions radiation [2].

Both indirect and direct allowed transitions are observed in TlInSe ${ }_{2}$ crystals. In [2-7] the width of the band gap of crystals was determined by different methods. In the experimental side, the optical band gap for $\mathrm{TIInSe}_{2}$ is found to be indirect and reported as $\approx 1.4 \mathrm{eV}$ at room temperature [2]. In another study the indirect band gap is claimed to be $1.2 \mathrm{eV}$ [3]. The indirect and direct band gaps of $\mathrm{TlInSe}_{2}$ are found 
$1.07 \mathrm{eV}$ and $1.35 \mathrm{eV}$, respectively in a different study [4]. From the fit to the most recent calculations of the energy bands of TlInSe 2 , direct-bandgap is $0.6 \mathrm{eV}$. The different values of the magnitude of the energy gap of 0.6 to $1.2 \mathrm{eV}$ and the transfer mechanisms are the result of a strong defect in the structure inherent in layered semiconductors and a manifestation of polytype. In [8] it was found that the introduction of elements of the first group increases the photosensitivity of $\mathrm{TlInSe}_{2}$ crystals due to the formation of «sensitizing» centers in them. The introduction of elements of the fourth group lowers the sensitivity threshold and the level of current noise as a result of partial compensation of holes caused by characteristic structural defects that are thermoacceptors.

On the basis of the TlInSe $\mathrm{I}_{2}$ compound in the system TlInSe $-\mathrm{D}^{\mathrm{IV}} \mathrm{Se}_{2}\left(\mathrm{D}^{\mathrm{IV}}-\mathrm{Si}, \mathrm{Ge}, \mathrm{Sn}\right)$ solid solutions are formed whose length is $35 \mathrm{~mol}$. \% $\mathrm{SiSe}_{2}, 25 \mathrm{~mol}$. \% $\mathrm{GeSe}_{2}, 28$ mol. \% $\mathrm{SnSe}_{2}$ [9]. In [10-12] the increase of the bandgap width with the increase of $\mathrm{SiSe}_{2}, \mathrm{GeSe}_{2}$, $\mathrm{SnSe}_{2}$ alloy composition was established. This is due to the mechanism of solid solution formation. Decreasing the parameters of the crystal lattice leads to an increase $E_{g}[13]$.

\section{Experimental results and their discussion}

Optical measurement constitutes the most-important means of determining the band structures of semiconductors. One of the main methods of research the defective state of a semiconductor is to study the energy dependence of the light absorption coefficient. Photoninduced electronic transitions can occur between different bands, which lead to the determination of the energy bandgap, or within a single band such as the freecarrier absorption. Optical measurements can also be used to study lattice vibrations (phonons).

By researching the spectra of light absorption by a semiconductor, we can obtain information about the structure of energy bands. Due to the peculiarities of the structure of the conduction band and valence band, semiconductors are divided into direct and indirect bandgap. A photon may be absorbed by the excitation of an electron from a filled state in the valence band to an empty state in the conduction band. This process is the main process in a photodetector or solar cell. Process in an LED is thus the reverse - an electron in the conduction band can spontaneously return to an empty state in the valence band (recombination), with the emission of a photon. Either for photon absorption or emission, the conventional theory for optical transitions between the valence and conduction bands of directbandgap materials is based on the so-called $\vec{k}$-selection rule. $\left(\vec{k}_{1}=\vec{k}_{2}\right)$. The allowed transitions are then between initial and final states of the same wave vector and are called direct or vertical transitions (in $E-k$ space). When the conduction-band minima are not at the same value of $\vec{k}$ as the valence band, assistance of a phonon is necessary to conserve crystal momentum, and the transition is called indirect.
At room temperature for $\mathrm{Tl}_{1-x} \mathrm{In}_{1-x} \mathrm{D}^{\mathrm{IV}}{ }_{x} \mathrm{Se}_{2}\left(\mathrm{D}^{\mathrm{IV}}-\mathrm{Si}\right.$, Ge, Sn, $x \leq 0,25)$ crystals the $\alpha=f(h v)$ dependencies are complex [10-12, 14]. Also, the edge of the fundamental absorption band shifts to the region of higher energies with increasing $x$ (increasing the alloy composition of $\mathrm{D}^{\mathrm{IV}} \mathrm{Se}_{2}\left(\mathrm{D}^{\mathrm{IV}}-\mathrm{Si}, \mathrm{Ge}, \mathrm{Sn}\right)$. This shift is due to two processes [9]: static replacement of indium atoms by silicon atoms (or germanium, tin) and an increase in the concentration of thallium vacancies $V_{\mathrm{Tl}}$. These processes are dominant in changing the bandgap [15]. Due to the static substitution of indium atoms $\left(\mathrm{In}^{+3}\right)$ by $\mathrm{D}^{\mathrm{IV}}$ atoms $\left(\mathrm{D}^{\mathrm{IV}}-\mathrm{Si}^{+4}, \mathrm{Ge}^{+4}, \mathrm{Sn}^{+4}\right)$ donor centers are formed. As a result of the formation of positively charged ions (donors) and negatively charged ions ( $V_{\mathrm{Tl}}$ - acceptors), the energy of the ionic bond between them increases. An increase in the bond energy between the atoms of the crystal leads to an increase in the $E_{g}$ and a decrease in the interatomic distance and hence the volume of the primitive cell of the alloys [9].

The Tauts method [16] was used to estimate the optical bandgap. Analysis of the absorption spectra at $T=300 \mathrm{~K}$ showed that in different energy ranges the experimental $\alpha=f(h v)$ dependences in all solid solutions are directed in the $(\alpha h v)^{1 / 2}$ and $(\alpha h v)^{2}$ coordinates. This indicates the realization in these solid solutions of both indirect and direct allowed transitions [10-12].

The dependences of the energy gap values on the mole fraction $x$ of the components $\mathrm{SiSe}_{2}, \mathrm{GeSe}_{2}$ and $\mathrm{SnSe}_{2}$ for $\mathrm{Tl}_{1-x} \mathrm{In}_{1-x} \mathrm{Si}_{x} \mathrm{Se}_{2}, \mathrm{Tl}_{1-x} \mathrm{In}_{1-x} \mathrm{Ge}_{x} \mathrm{Se}_{2}(x \leq 0.2)$ and $\mathrm{Tl}_{1-x} \mathrm{In}_{1-x} \mathrm{Sn}_{x} \mathrm{Se}_{2} \quad(x \leq 0.25)$ crystalline compounds were established by optical measurements. Figure 1 shows the energy gap for $\mathrm{Tl}_{1-x} \mathrm{In}_{1-x} \mathrm{Si}_{x} \mathrm{Se}_{2}, \quad \mathrm{Tl}_{1-x} \mathrm{In}_{1-x} \mathrm{Ge}_{x} \mathrm{Se}_{2} \quad \mathrm{i}$ $\mathrm{Tl}_{1-x} \mathrm{In}_{1-x} \mathrm{Sn}_{x} \mathrm{Se}_{2}$ as a function of the mole fraction $x$.

For $0 \leq x<0.1$, the energy gap is direct. For $x \geq 0.1$, the energy gap is indirect and increasing (Table 1).

Figure 2 shows the corresponding energymomentum plots for alloy compositions. As indicated, the conduction band has two minima. The one along the $\mathrm{H}$-axis is the direct minimum, whereas the one along the $\mathrm{Z}$-axis is the indirect minimum. This energy-momentum diagram does not contradict $[6,17]$. Electrons in the direct minimum of the conduction band and holes at the top of the valence band have equal momentum; while electrons in the indirect minimum have different momentum. For direct-bandgap semiconductors, such as TIInSe ${ }_{2}, \quad \mathrm{Tl}_{1-x} \mathrm{In}_{1-x} \mathrm{Si}_{x} \mathrm{Se}_{2}, \quad \mathrm{Tl}_{1-x} \mathrm{In}_{1-x} \mathrm{Ge}_{x} \mathrm{Se}_{2} \quad$ and $\mathrm{Tl}_{1-x} \mathrm{In}_{1-x} \mathrm{Sn}_{x} \mathrm{Se}_{2}(x<0.1)$, the momentum is conserved and interband transitions may occur with high probability. The photon energy is then approximately equal to the bandgap energy of the semiconductor. The radiative transition mechanism is predominant indirect band gap materials. However, for $\mathrm{Tl}_{1-x} \mathrm{In}_{1-x} \mathrm{Si}_{x} \mathrm{Se}_{2}, \mathrm{Tl}_{1-x} \mathrm{In}_{1-x} \mathrm{Ge}_{x} \mathrm{Se}_{2} \mathrm{i}$ $\mathrm{Tl}_{1-x} \mathrm{In}_{1-x} \mathrm{Sn}_{x} \mathrm{Se}_{2}$ at $x \geq 0.1$ that are indirect bandgap semiconductors, the probability for interband transitions is extremely small, since phonons or other scattering agents must participate in the process to conserve momentum. Therefore, for indirect bandgap semiconductors, a special types of recombination centers are incorporated to enhance the radiative transition. 


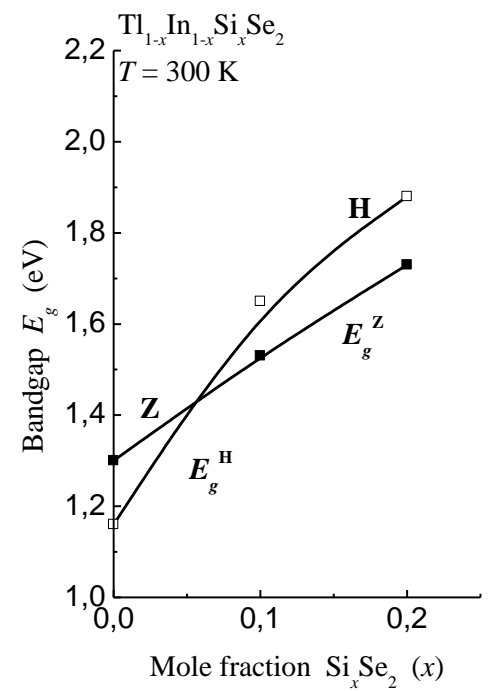

(a)

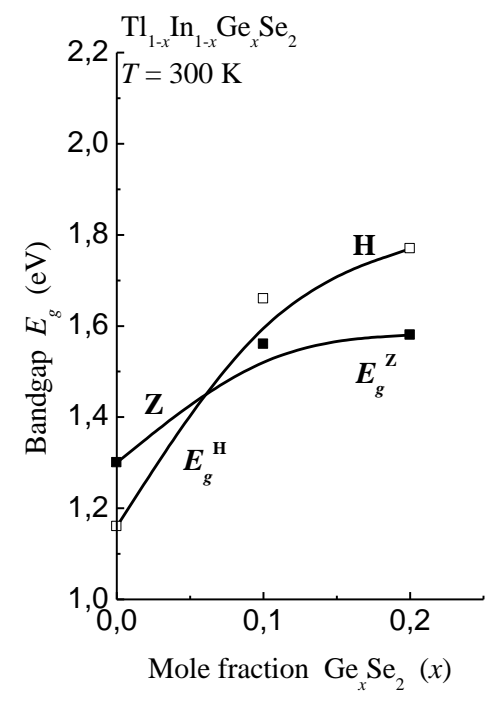

(b)

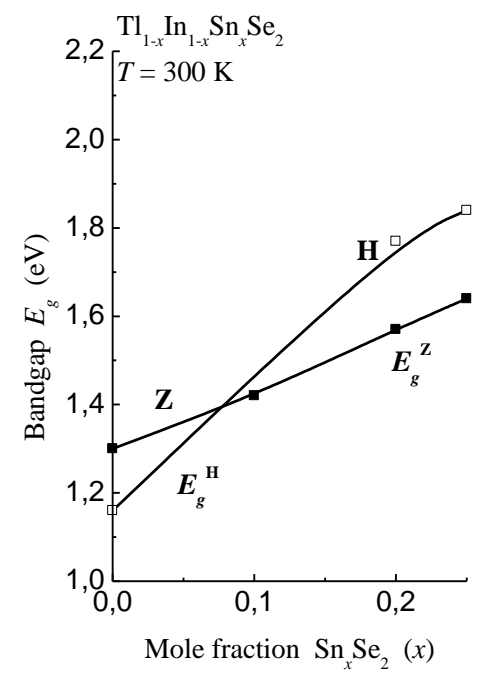

(c)

Fig. 1. Composition dependence of the direct $(\mathrm{H})$ and indirect $(\mathrm{Z})$ bandgap $E_{g}=f(x)$ for (a) $\mathrm{SiSe}_{2},(\mathrm{~b}) \mathrm{GeSe}_{2}$, and (c) $\mathrm{SnSe}_{2}$.

Table 1

The dependences of the energy gap values on the mole fraction $x$ of the components $\mathrm{SiSe}_{2}, \mathrm{GeSe}_{2}$ and $\mathrm{SnSe}_{2}$

\begin{tabular}{|c|c|c|c|c|}
\hline From $E_{g}, \mathrm{eV}$ & At $x$ & To $E_{g}, \mathrm{eV}$ & At $x$ & For compounds \\
\hline 1.53 & 0.1 & 1.73 & 0.2 & $\mathrm{Tl}_{1-x} \mathrm{In}_{1-x} \mathrm{Si}_{x} \mathrm{Se}_{2}$ \\
\hline 1.56 & 0.1 & 1.58 & 0.2 & $\mathrm{Tl}_{1-x} \mathrm{In}_{1-x} \mathrm{Ge}_{x} \mathrm{Se}_{2}$ \\
\hline 1.42 & 0.1 & 1.64 & 0.25 & $\mathrm{Tl}_{1-x} \mathrm{In}_{1-x} \mathrm{Sn}_{x} \mathrm{Se}_{2}$ \\
\hline
\end{tabular}

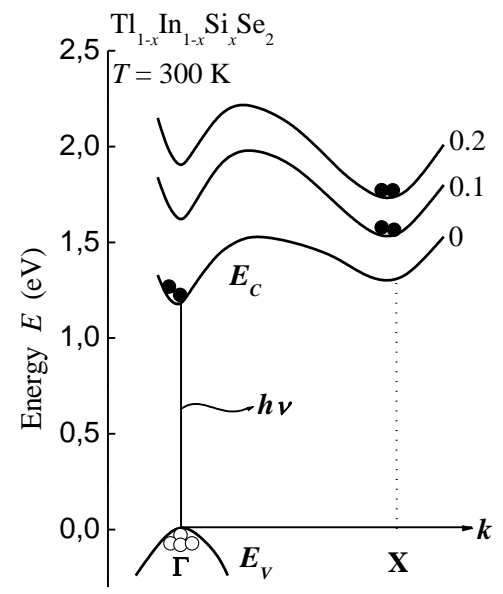

(a)

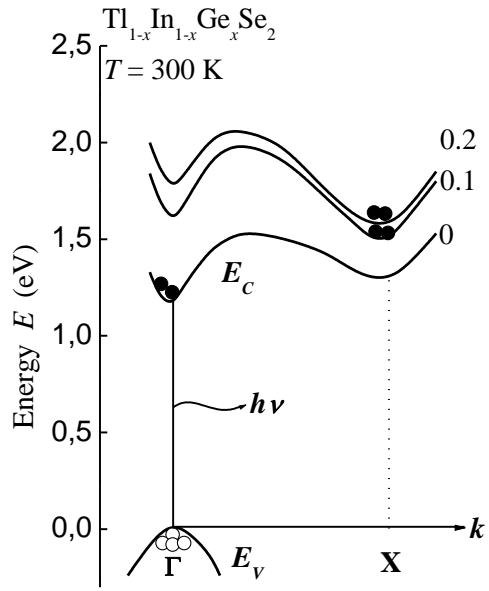

(b)

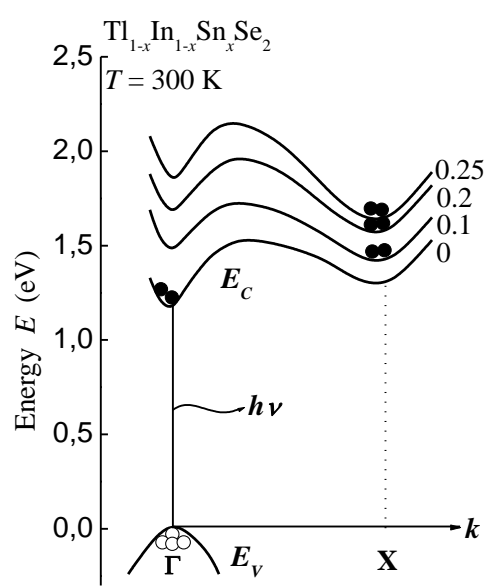

(c)

Fig. 2. Energy-momentum diagram for (a) $\mathrm{Tl}_{1-x} \mathrm{In}_{1-x} \mathrm{Si}_{x} \mathrm{Se}_{2}$, (b) $\mathrm{Tl}_{1-x} \mathrm{In}_{1-x} \mathrm{Ge}_{x} \mathrm{Se}_{2}$, and (c) $\mathrm{Tl}_{1-x} \mathrm{In}_{1-x} \mathrm{Sn}_{x} \mathrm{Se}_{2}$.

As shown in Fig. 1, the $\mathrm{Tl}_{1-x} \mathrm{In}_{1-x} \mathrm{Si}_{x} \mathrm{Se}_{2}$, $\mathrm{Tl}_{1-x} \mathrm{In}_{1-x} \mathrm{Ge}_{x} \mathrm{Se}_{2}$ and $\mathrm{Tl}_{1-x} \mathrm{In}_{1-x} \mathrm{Sn}_{x} \mathrm{Se}_{2}$ systems cover a very wide range of the spectrum, from the infrared to the beginning of the visible spectrum $(1.07 \div 0.72 \mu \mathrm{m})$. The direct-indirect bandgap transition occurs at about 1.40$1.45 \mathrm{eV}\left(\mathrm{SiSe}_{2}, \mathrm{GeSe}_{2}\right.$, and $\mathrm{SnSe}_{2}$ between 6 - $9 \%$ ), and for wavelength generation in the indirect bandgap regime, the efficiency is very low.

An efficient radiative recombination center can be introduced by incorporating specific impurities [18].
When carbon is introduced, it replaces some of the silicon, germanium or tin atoms in the lattice sites. The outer electronic structure of carbon is similar to that of silicon (or germanium, tin) (both are Group-IV elements in the periodic table), but the electronic core structures of these atoms differ considerably. This difference gives rise to an electron trap level close to the conduction band. A recombination center produced this way is called an isoelectronic center. Another type of isoelectronic center for $\mathrm{SiSe}_{2}, \mathrm{GeSe}_{2}$, and $\mathrm{SnSe}_{2}$ is possible. The isoelectronic 
centers are normally neutral. Under operation, an injected electron is first trapped at this center. The negatively charged center then captures a hole from the valence band to form a bound exciton. The subsequent annihilation of this electron hole pair yields a photon with energy equal to the bandgap minus energy approximately equal to the binding energy of the center. Such a system and operation can be visualized in the $E-k$ diagram shown in Fig. 3a. Conservation of momentum is not violated here because the isoelectronic traps are highly localized in space, and because of the Uncertainty principle, they have a wide range in the $k$-space (momentum). The described mechanism of radiative recombination in indirect bandgap materials is predominant.

Figure $3 b$ shows the quantum efficiency versus alloy composition $\eta=f(x)$ for $\mathrm{Tl}_{1-x} \mathrm{In}_{1-x}(\mathrm{Si}, \mathrm{Ge}, \mathrm{Sn})_{x} \mathrm{Se}_{2}$ with and without the isoelectronic impurity. The efficiency without impurities drops sharply in the composition range $0.06<x<0.09$ because of the proximity of the direct-indirect- $E_{g}$ transition. The efficiency with the isoelectronic impurity is considerably higher for $x>0.1$, but still decreases steadily with increasing $x$ because of the increasing separation in momentum between the direct and indirect bandgap (Fig. 2).

Photodetectors are important in optical-fiber communication systems operated in the near-infrared region $(0.8$ to $1.6 \mu \mathrm{m})$. They demodulate optical signals, that is, convert the optical variations into electrical variations that are subsequently amplified and further processed. Photodetectors must satisfy stringent requirements such as high sensitivity at operating wavelengths, high response speed, and minimum noise.

When incident light falls on the surface of the photoconductor, carriers are generated either by band-toband transitions (intrinsic) or by transitions involving forbidden-gap energy levels (extrinsic), resulting in an increase in conductivity $\sigma_{i}>\sigma_{d}\left(\sigma_{d}\right.$ is the dark conductivity). For the intrinsic photoconductor, the conductivity is given by $\sigma=q\left(\mu_{n} n+\mu_{p} p\right)$, and the increase of conductivity under illumination is mainly due to the increase in the number of carriers. The wavelength cutoff is given by $\lambda=\frac{h c}{\Delta E}=\frac{1.24}{\Delta E(\mathrm{eV})} \mu \mathrm{m}$, where $\Delta E$ is the semiconductor bandgap $E_{g}$ in this case. Since usually photon energy $h v>\Delta E$ can also cause excitation, $\lambda$ is often the maximum wavelength limit for detection. For shorter wavelengths, the incident radiation is absorbed by the semiconductor, and electron-hole pairs are generated. For the extrinsic photoconductor, photoexcitation occurs between a band edge and an impurity energy level in the energy gap.

$\mathrm{Tl}_{1-x} \mathrm{In}_{1-x} \mathrm{D}^{\mathrm{IV}}{ }_{x} \mathrm{Se}_{2}\left(\mathrm{D}^{\mathrm{IV}}-\mathrm{Si}, \mathrm{Ge}, \mathrm{Sn}\right)$ crystals are photosensitive materials [10-12] (on the $\sigma / \sigma_{\max }=f(\lambda)$ spectral distribution there is an increase in photoconductivity $\sigma_{i}>\sigma_{d}$ ). But they react differently to light at room temperature in the wavelength range from 0.4 to $1.4 \mu \mathrm{m}$ (Fig. 4 ).

For TlInSe $\mathrm{S}_{2}$ at room temperature, the maximum photoconductivity is $\lambda \approx 0.9 \mu \mathrm{m}$, and the bandgap is $1.12 \mathrm{eV}$ [4]. When $\mathrm{D}^{\mathrm{IV}}{ }_{x} \mathrm{Se}_{2}\left(\mathrm{D}^{\mathrm{IV}}-\mathrm{Si}, \mathrm{Ge}, \mathrm{Sn}\right)$ is added and their mole fraction increases, the maximum photoconductivity shifts to the short-wavelength region. At a temperature of $300 \mathrm{~K}$ for $\mathrm{Tl}_{1-x} \mathrm{In}_{1-x} \mathrm{Si}_{x} \mathrm{Se}_{2} \quad \lambda \approx 0.91$ and $0.81 \mu \mathrm{m}$ (Fig. $4 \mathrm{a}$, curves $1^{\prime}$ and $1^{\prime \prime}$ ). The energies of these transitions were estimated from the longwavelength edge of the photoconductivity and were $\approx$ 1.26 and $1.42 \mathrm{eV}$. Such transitions can correspond to indirect transitions of electrons from the valence band to the valleys of the conduction band (with phonon radiation) (Fig. 2a). For $\mathrm{Tl}_{1-x} \mathrm{In}_{1-x} \mathrm{Ge}_{x} \mathrm{Se}_{2} \lambda \approx 1.03$ and $0.95 \mu \mathrm{m}$ (Fig. $4 \mathrm{a}$, curves $2^{\prime}$ and $2^{\prime /}$ ), and respectively $E \approx$

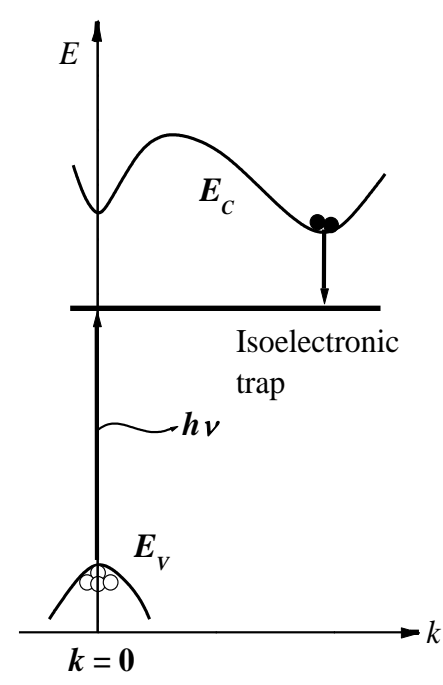

(a)

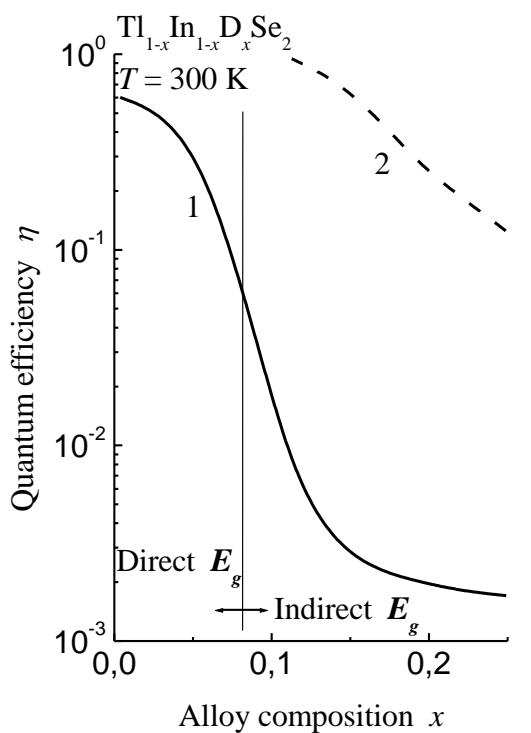

(b)

Fig. 3. (a) $E-k$ diagram showing radiative recombination through an isoelectronic trap in indirect bandgap material, (b) Quantum efficiency of $\mathrm{Tl}_{1-x} \mathrm{In}_{1-x} \mathrm{D}^{\mathrm{IV}}{ }_{x} \mathrm{Se}_{2}\left(\mathrm{D}^{\mathrm{IV}}-\mathrm{Si}, \mathrm{Ge}, \mathrm{Sn}\right)$ vs. alloy composition $\eta=f(x)$, with (1) and without (2) isoelectronic impurity. 


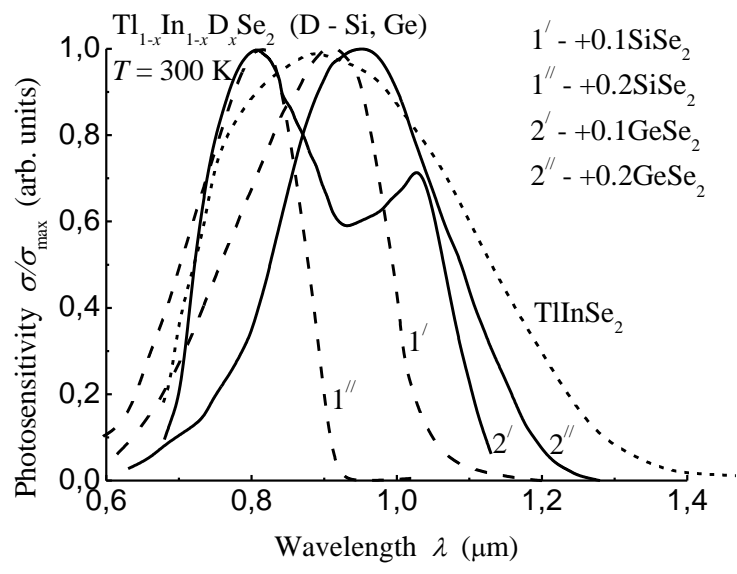

(a)

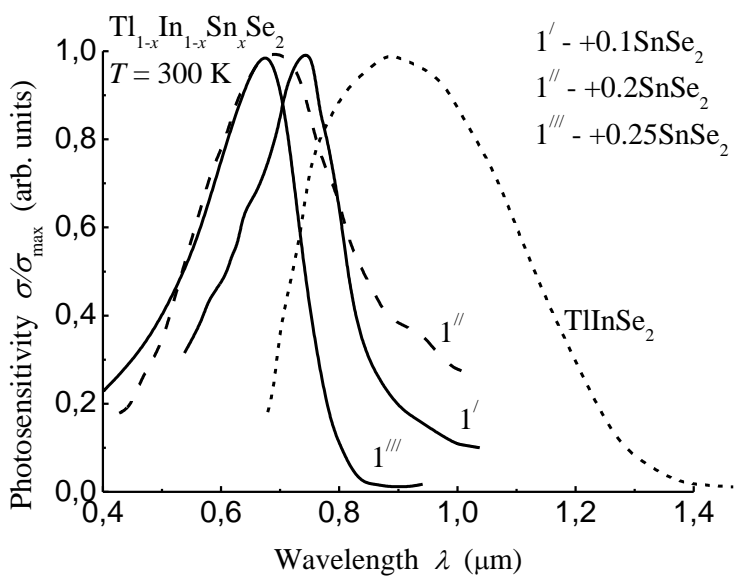

(b)

Fig. 4. Spectral distribution of photoconductivity $\sigma / \sigma_{\max }=f(\lambda)$ for (a) $\mathrm{Tl}_{1-x} \mathrm{In}_{1-x} \mathrm{D}^{\mathrm{IV}}{ }_{x} \mathrm{Se}_{2}\left(\mathrm{D}^{\mathrm{IV}}-\mathrm{Si}, \mathrm{Ge}\right)$, (b) $\mathrm{Tl}_{1-x} \mathrm{In}_{1-x} \mathrm{Sn}_{x} \mathrm{Se}_{2}$

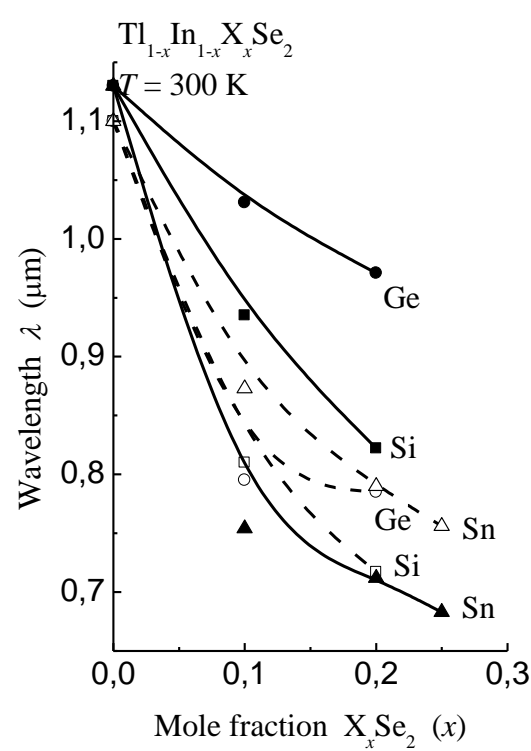

(a)

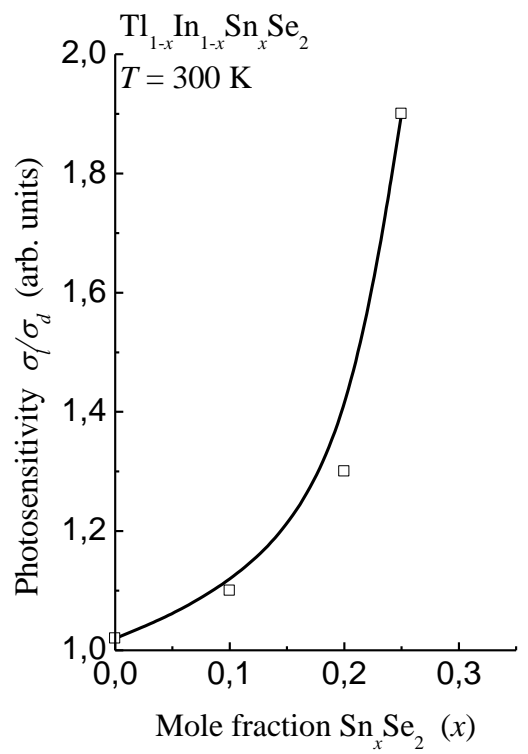

(b)

Fig. 5. (a) The wavelength cutoff photoconductivity $\lambda=f(x)$, (b) The maximum photosensitivity $\sigma_{i} / \sigma_{d}=f(x)$ for $\mathrm{Tl}_{1-x} \mathrm{In}_{1-x} \mathrm{D}^{\mathrm{IV}}{ }_{x} \mathrm{Se}_{2}\left(\mathrm{D}^{\mathrm{IV}}-\mathrm{Si}, \mathrm{Ge}, \mathrm{Sn}\right)$ at $T=300 \mathrm{~K}$ as a function of the mole fraction $\mathrm{SiSe}_{2}, \mathrm{GeSe}_{2}$ i $\mathrm{SnSe}_{2}$.

1.15 and $1.17 \mathrm{eV}$. For $\mathrm{Tl}_{0.9} \mathrm{In}_{0.9} \mathrm{Ge}_{0.1} \mathrm{Se}_{2}$ (Fig. 4a, curve $2^{\prime}$ ) some photoconductivity is observed at $0.8 \mu \mathrm{m}$, which obviously corresponds to direct phototransitions of electrons or transitions from deeper valence bands to Cband valleys (Fig. 2b). The estimated transition energy is $\approx 1.35 \mathrm{eV}$. With increasing $x$ in the $\mathrm{Tl}_{1-x} \mathrm{In}_{1-x} \mathrm{Sn}_{x} \mathrm{Se}_{2}$ compounds, the maximum photoconductivity changes its position from $\lambda \approx 0.75 \mu \mathrm{m}$ (at $x=0.1$ ) to $\lambda \approx 0.66 \mu \mathrm{m}$ (at $x=0.25$ ) (Fig. 4b). The energies of these transitions were $\approx 1.53,1.59$ and $1.69 \mathrm{eV}$.

The photoconductivity maxima for all compounds at a temperature of $300 \mathrm{~K}$ are in the region of fundamental transitions or close to it and are the maxima of intrinsic photoconductivity. For $\mathrm{Tl}_{1-x} \mathrm{In}_{1-x} \mathrm{Ge}_{x} \mathrm{Se}_{2} \lambda \approx 1.03,0.8$ (at $x=0.1$ ) and $0.95 \mu \mathrm{m}$ (at $x=0.2$ ). In the $\mathrm{Tl}_{1-x} \mathrm{In}_{1-x} \mathrm{Sn}_{x} \mathrm{Se}_{2}$ compounds the maximum photoconductivity changes its position with increasing $x$ from $\lambda \approx 0.75 \mu \mathrm{m}$ (at $x=0.1$ ) to $\lambda \approx 0.66 \mu \mathrm{m}$ (at $x=0.25$ ) (Fig. $4 \mathrm{~b}$ ). This is due to the change in the width of the band gap for different $x$.

\section{Conclusions}

Semiconducting ternary compounds of the TlInSe 2 type, the band gap of which at room temperature is 1.3 $1.9 \mathrm{eV}$, are promising as functional materials of modern optoelectronic technology for use in photon and photovoltaic. The change in the physical properties of the molar content of the components $x$ associated with the rearrangement of the band structure expands the 
functional capabilities of the crystalline compounds TlInSe $-\mathrm{D}^{\mathrm{IV}} \mathrm{Se}_{2}\left(\mathrm{D}_{\mathrm{IV}}-\mathrm{Si}, \mathrm{Ge}, \mathrm{Sn}\right)$.

The article establishes at a temperature of $\mathrm{T}=300 \mathrm{~K}$ the main photonic parameters of crystals of solid solutions $\mathrm{TlInSe}_{2}-\mathrm{D}^{\mathrm{IV}} \mathrm{Se}_{2}\left(\mathrm{D}^{\mathrm{IV}}-\mathrm{Si}, \mathrm{Ge}, \mathrm{Sn}\right.$ ) from the molar content of $\mathrm{SiSe}_{2}, \mathrm{GeSe}_{2}$, and $\mathrm{SnSe}_{2}$, as used as functional materials for optoelectronic devices. Therefore, having a well-established technology for obtaining crystalline compounds $\mathrm{Tl}_{1-\mathrm{x}} \mathrm{In}_{1-\mathrm{x}} \mathrm{D}^{\mathrm{IV}} \mathrm{SSe}_{2}\left(\mathrm{D}^{\mathrm{IV}}-\right.$ $\mathrm{Si}, \mathrm{Ge}, \mathrm{Sn})$, it is possible to obtain multifunctional materials for optoelectronic devices. By changing the molar content of the components $\mathrm{x}$, it is possible to predictably change the mechanisms of interband transitions in semiconductors, expanding the practical use of the material for light or photographic devices.

Danylchuk S.P. - senior laboratory assistant;

Zamurujeva O.V. - Ph.D., Associate Professor, Senior Researcher;

Sakhnyuk V.E. - Ph.D., Associate Professor, Head of the Department of Theoretical and Computer Physics;

Fedosov S.A. - Professor, Dr. Sci.

[1] I.V. Alekseev, Izv. AN USSR. Inorg. Mater. 28, 2404 (1992).

[2] E. Kerimova, S. Mustafaeva, D. Guseinova, et al., Phys. Status Solidi A, 179(1), 199 (2000); https://doi.org/10.1002/1521-396X(200005)179:1<199::AID-PSSA199>3.0.CO;2-W.

[3] A.E. Bakhyshov, M.F. Agaeva, A.M. Darvish, Phys. Status Solidi B 91(1), K31 (1979); https://doi.org/10.1002/pssb.2220910152.

[4] M. Hanias, A.N. Anagnostopoulos, K. Kambas, J. Spyridelis. Physica B 160(2), 154 (1989); https://doi.org/10.1016/0921-4526(89)90050-1.

[5] H.Y. Fan, Rep. Progr. Phys. 19(1), 107 (1956); https://doi.org/10.1088/0034-4885/19/1/304.

[6] O. Yildirim, Energy bands of TISe and TIInSe ${ }_{2}$ in tight binding model. 2005. PhD Thesis. Middle East Technical University.

[7] G. Orudzhev, N. Mamedov, H. Uchiki, et al., J. Phys. Chem. Solids 64(9-10), 1703 (2003); https://doi.org/10.1016/S0022-3697(03)00073-8.

[8] I. Nuritdinov, S.K. Umarov, V.D. Rustamov, J. Perspektivnye materialy (1), 46 (2003); http://j-pm.imetdb.ru/?archive\&a=174\#.

[9] M.Yu. Mozolyuk, L.V. Piskach, A.O. Fedorchuk, et al., J. Alloys Compd. 509(6), 2693 (2011); https://doi.org/10.1016/j.jallcom.2010.11.112.

[10] G.L. Myronchuk, O.V. Zamurueva, O.V. Parasyuk, et al., J. Mater. Sci.: Mater. Electron 25(7), 3226 (2014); https://doi.org/10.1007/s10854-014-2007-y.

[11] O.V. Zamurueva, G.L. Myronchuk, G. Lakshminarayana, et al., Optical Mater. 37, 614 (2014); https://doi.org/10.1016/j.optmat.2014.08.004.

[12] G.L. Myronchuk, G.E. Davydyuk, O.V. Parasyuk, et al., J. Mater. Sci.: Mater. Electron. 24(9), 3555 (2013); DOI:10.1007/s10854-013-1285-0.

[13] J.I. Pankove, Optical Processes in Semiconductors (Mir, Moscow, 1973).

[14] G.E. Davydyuk, O.Y. Khyzhun, A.H. Reshak, et al., Phys. Chem. Chem. Phys. 15, 6965 (2013); https://doi.org/10.1039/C3CP50836F.

[15] G.E. Davydyuk, M. Piasecki, O.V. Parasyuk, et al., Opt. Mater. 35(12), $2514 \quad$ (2013); https://doi.org/10.1016/j.optmat.2013.07.012.

[16] J. Tauc, R. Grigorovici, A. Vancu, Phys. Status Solidi B 15(2), 627 (1966); https://doi.org/10.1002/pssb.19660150224.

[17] M. Piasecki, G.L. Myronchuk, O.V. Zamurueva, et al., Huge Operation by Energy Gap of Novel Narrow Band Gap $\mathrm{Tl}_{1-\mathrm{x}} \mathrm{In}_{1-\mathrm{x}} \mathrm{B}_{\mathrm{x}} \mathrm{Se}_{2}(\mathrm{~B}=\mathrm{Si}, \mathrm{Ge})$ : DFT, X-ray Emission and Photoconductivity Studies. Mater. Res. Express, 3(2), 025902 (2016); https://doi.org/10.1088/2053-1591/3/2/025902.

[18] W.O. Groves, A.H. Herzog, M.G. Craford, Appl. Phys. Lett. 19(6), $184 \quad$ (1971); https://doi.org/10.1063/1.1653876. 


\section{С.П. Данильчук, О.В. Замуруєва, В.С. Сахнюк, С.А. Федосов \\ Фотонні властивості пристроїв на основі багатокомпонентних кристалічних сполук із вмістом (Si, Ge, Sn)}

Волинський національний університет імені Лесі Українки, Луцьк, Украӥна, zaтигиеvа.о@gтаil.com

У роботі представлені результати оптичних і фотоелектричних вимірювань та їх аналіз для кристалічних сполук $\mathrm{Tl}_{1-x \mathrm{In}}{ }_{1-x} \mathrm{D}^{\mathrm{IV}}{ }_{x} \mathrm{Se}_{2}\left(\mathrm{D}^{\mathrm{IV}}-\mathrm{Si}, \mathrm{Ge}, \mathrm{Sn}\right)$ у діапазоні довжин хвиль $0,4 \div 1,4$ мкм при температурі $T=300$ K. Робота переслідує мету дослідити вплив молярного вмісту $\mathrm{D}^{\mathrm{IV}} \mathrm{Se}_{2}$ на механізми міжзонних переходів та основні фотонні параметри кристалів твердих розчинів $\mathrm{TlInSe}-\mathrm{D}^{\mathrm{IV}} \mathrm{Se}_{2}$. Встановлено, що зміна фізичних властивостей від молярного вмісту компонент $x$, пов'язаних 3 перебудовою зонної структури, значно розширює функціональні можливості кристалічних сполук $\mathrm{Tl}_{1-x} \mathrm{In}_{1-x}(\mathrm{Si}, \mathrm{Ge}, \mathrm{Sn})_{x} \mathrm{Se}_{2}(x \leq 0,25)$, як перспективних матеріалів оптоелектронних пристроїв.

Ключові слова: кристал, молярний вміст, прямі та непрямі переходи, енергетична щілина, коефіцієнт поглинання, фоточутливість. 